\title{
Erupsi Gigi Insisivus Pertama Permanen Rahang Bawah Berdasarkan Letak Geografis Pesisir Pantai dan Pegunungan Di Kabupaten Pacitan
}

\author{
Ayun Inesta Putri ${ }^{1}$, Agus Marjianto ${ }^{2}$, Sri Hidayati ${ }^{3}$ \\ ${ }^{1,2,3}$ Poltekkes Kemenkes Surabaya Jurusan Keperawatan Gigi \\ Email : putriinesta@gmail.com
}



Kata kunci:

Erupsi gigi; Insisivus Pertama

Permanen Rahang Bawah; Letak Geografis

\section{ABSTRAK}

Masalah dalam penelitian ini perbedaan erupsi gigi insisivus pertama permanen rahang bawah berdasarkan letak geografis pesisir pantai dan pegunungan Kabupaten Pacitan. Tujuan penelitian ini adalah untuk mengetahui perbedaan erupsi gigi insisivus pertama permanen rahang bawah berdasarkan letak geografis pesisir pantai dan pegunungan Kabupaten Pacitan. Jenis penelitian yang digunakan adalah penelitian observasional analitik dengan pendekatan cross sectional. Sampel dalam penelitian ini adalah sebagian siswa pada SD di daerah pesisir pantai yaitu Kecamatan Ngadirojo dan Kecamatan Pacitan serta SD yang terletak di daerah pegunungan yaitu Kecamatan Tulakan dan Kecamatan Tegalombo dengan jumlah minimal sampel 111 anak. Metode yang digunakan untuk pengumpulan data yaitu metode observasi dan dokumentasi.Teknik analisis yang digunakan yaitu teknik analisis data chi-square dengan $\alpha=0,05$. Hasil penelitian didapatkan bahwa untuk uji normalitas data gigi insisivus pertama permanen rahang bawah $(31,41)$ baik didaerah pegunungan maupun pesisir pantai yaitu 0,000 sehingga sig $\leq 0,05$ yang menunjukkan bahwa data tidak normal. Uji chi-square elemen gigi 31 menunjukkan nilai sig 0,005 sehingga sig $\leq 0,05$ dan elemen gigi 41 nilai sig 0,003 sehingga sig $\leq 0,05$. Hal ini berarti bahwa $\mathrm{H} 1$ diterima yaitu terdapat perbedaan erupsi gigi insisivus pertama permanen rahang bawah berdasarkan letak geografis daerah pesisir pantai dan pegunungan Kabupaten Pacitan.

Key word:

Tooth eruption; Lower Jaw Permanent First Incisor; Geographical location

\section{ABSTRACT}

Background: The problem in this study is the difference in the eruption of the mandibular first permanent incisor based on the geographical location of the coast and mountains of Pacitan Regency. Purpose:The purpose of this study was to determine the differences in the eruption of mandibular first permanent incisors based on the geographical location of the coast and mountains of Pacitan Regency. Methods:This type of research is analytic observational research with a cross sectional approach. The sample in this study were some students at elementary schools in coastal areas, namely Ngadirojo and Pacitan districts, and elementary schools located in mountainous areas, namely Tulakan and Tegalombo districts, with a minimum sample size of 111 children. The method used for data collection is the method of observation and documentation. The analysis technique used is the chi-square data analysis technique with $\alpha=0.05$. Result:The results showed that the data normality test for the mandibular first permanent incisor (31.41) both in mountainous and coastal areas was 0.000 so that $\operatorname{sig} \leq$ 0.05 , which indicates that the data is not normal. The chi-square test of dental element 31 shows a sig value of 0.005 so that sig $\leq 0.05$ and tooth element 41 a sig value of 0.003 so that sig $\leq 0.05$. This means that $\mathrm{H} 1$ is accepted, namely that there is a difference in the eruption 


\section{PENDAHULUAN}

Erupsi gigi diartikan sebagai pergerakan gigi pada tempat pembentukannya didalam tulang alveolar ke arah dataran oklusal pada kavitas oral.Erupsi gigi dapat dipengaruhi oleh berbagai faktor yang berbeda pada setiap individu antara lain sosial ekonomi, gizi, jenis kelamin,ras, hormonal dan genetik (1).

Pola erupsi gigi permanen ditinjau dari usia kronologis pada anak usia 6 sampai 12 tahundi SDN Sirnasari Desa Ciptasari Kecamatan Pamulihan Kabupaten Sumedang bahwa waktu erupsi gigi rahang bawah, gigi insisif pertama erupsi pada umur rata-rata 6,00 tahun(2).

Kabupaten Pacitan merupakan Kabupaten yang terletak di Pantai Selatan Pulau Jawa dan memiliki karakteristik wilayah perbukitan ( $85 \%$ dari luas wilayah) dan merupakan kawasan ekokarst. Adapun wilayah administrasi Kabupaten Pacitan yaitu memiliki 12 Kecamatan, 5 Kelurahan dan 166 Desa (total 171 Desa/Kelurahan) dengan letak geografis berada antara $110^{\circ} 55^{\prime}-111^{\circ} 25^{\prime}$ Bujur Timur dan $7^{\circ} 55^{\prime}-8^{\circ} 17^{\prime}$ Lintang Selatan (3).

Berada di Laut Selatan, maka potensi yang bisa diambil dari laut pun sangat banyak. Seperti diketahui, bahwa luas wilayah laut Kabupaten Pacitan mencapai 7.636 mil persegi dengan 12 pantai merupakan daerah untuk pendaratan ikan oleh nelayan. Sehingga potensi wilayah laut tersebut sebesar kurang lebih 84.4330 ton pertahun, dan ikan lobster mempunyai daya jual yang cukup tinggi di Pacitan. Tangkapan ikan dan lobster yang dihasilkan, hasilnya dikonsumsi penduduk dan dijual ke luar daerah (3).

Daerah pesisir pantai di Kabupaten Pacitan diantaranya yaitu Kecamatan Ngadirojo. Kecamatan Ngadirojo yang terletak di sebelah timur dari ibu kota Pacitan memiliki jarak $+40 \mathrm{Km}$ dari kota dengan luas wilayah $+9.590 .54 \mathrm{Ha}$. Pantai yang terletak di wilayah Kecamatan Ngadirojo berjumlah 5 pantai yang meliputi pantai soge, pantai puring, pantai siwil, pantai tawang, pantai taman dan pantai breman (3).

Kabupaten Pacitan merupakan kabupaten dengan luas wilayah perbukitan sebanyak $85 \%$ dari luas wilayah secara keseluruhan. Daerah perbukitan dominan akan sayurmayur, palawija, dan hasil perkebunan, sehingga sebagian besar penduduknya bekerja pada sektor pertanian. Komoditi pertanian yang dikembangkan di Pacitan meliputi komoditi kelapa, cengkeh, kopi, kakao, lada, kapas, jarak pagar, nilam, tembakau, dll (3).

Daerah perbukitan ini diantaranya yaitu Kecamatan Tulakan. Kecamatan Tulakan memiliki luas wilayah $161,61 \mathrm{~km} 2$ dengan wilayah terluas berjenis tanah kering seluas $143,44 \mathrm{~km} 2$ atau 88,76 persen dari total wilayah Kecamatan Tulakan dan sisanya berjenis tanah sawah. Potensi perekonomian wilayah Kecamatan Tulakan masih didominasi sektor pertanian (3). 
Perbedaan jenis komoditi ini menyebabkan perbedaan jenis dan jumlah pangan yang biasa dikonsumsi sehari-hari. Masyarakat di daerah pantai yang sebagian besar adalah nelayan cenderung mengkonsumsi makanan sumber protein hewani yang berasal dari laut, sedangkan masyarakat di daerah perbukitan (dataran tinggi) yang sebagian besar adalah petani sawah atau ladang cenderung mengkonsumsi makanan sumber protein nabati (4).

Ikan merupakan sumber protein dan kalsium dengan kualitas tinggi. Kandungan gizi ikan ini sangat bagus untuk tulang dan gigi. Makanan dengan kualitas dan konsentrasi protein dan kalsium yang tinggi mempunyai hubungan linier dengan pertumbuhan dan perkembangan tulang dan gigi. Hal ini disebabkan protein merupakan makanan yang mengandung banyak asam amino sebagai unsur pembangun struktur jaringan tubuh, sedangkan kalsium merupakan mineral penting yang berperan dalam seluruh proses metabolisme tulang dan gigi (5).

Penelitian Rahmawati (2014) di Kecamatan Kasihan Bantul,DIY yang merupakan daerah pegunungan sebagian besar penduduk bekerja sebagai petani, dan mengkonsumsi sumber makanan protein nabati. Hasilnya di dapatkan 30 siswa usia 67 tahun status gizi baik, yang sudah erupsi 28 (80\%) dan yang belum erupsi $2(20 \%)$. Tahapan erupsi gigi yang sudah erupsi sempurna 75\%, erupsi sebagian $21,7 \%$ dan belum erupsi 3,3\%(6).

Penelitian Lantu., dkk (2015) di Manado yang merupakan daerah pesisir pantai. Hasilnya dari 49 responden usia 6-7 tahun didapat $53 \%$ belum mengalami erupsi gigi dan $47 \%$ sudah mengalami erupsi gigi(7). Hal ini menandakan bahwa di daerah pesisir pantai mengalami perlambatan erupsi gigi, tidak sesuai dengan hasil penelitian yang telah di kemukakan oleh Bozini dkk., 2011.Penelitian ini bertujuan untuk Untuk mengetahui perbedaan waktu erupsi gigi insisivus perberdasarkan letak geografis pesisir pantai dan pegunungan Kabupaten Pacitan.

\section{METODE}

Penelitian ini telah melalui persetujuan komisi etik penelitian kesehatan Poltekkes Kemenkes Surabaya No.EA/0113/KEPK-Poltekkes_Sby/V/2019. Jenis penelitian yang dilakukan dalam penelitian ini adalah penelitian observasional analitik dengan pendekatan cross sectional. Populasi dalam penelitian ini seluruh siswa pada SD di daerah pesisir pantai yaitu Kecamatan Ngadirojo serta SD yang terletak di daerah pegunungan yaitu Kecamatan Tulakan, Kabupaten Pacitan dengan rentang usia 6-7 tahun. Sampel dalam penelitian ini sebagian siswa pada SD di daerah pesisir pantai yaitu Kecamatan Ngadirojo serta SD yang terletak di daerah pegunungan yaitu Kecamatan Tulakan, Kabupaten Pacitan dengan rentang usia 6-7 tahun. Dalam mencari besar sampel penelitian ini menggunakan rumus jumlah perhitungan sampel minimal rerata untuk 2 populasi (mean)jumlah minimal sampel untuk didaerah pesisir pantai yaitu 111 anak serta untuk pegunungan sebanyak 111 anak.

Metode pengumpulan data Metode yang digunakan untuk pengumpulan data yaitu metode observasi dan dokumentasi.

Pengumpulan data dalam penelitian inianak menyerahkan informed consent yang telah diisi oleh orangtua atau wali siswa, anak dikelompokkan berdasarkan jenis 
kelamin, Anak dipersilahkan duduk, peneliti mengisi data anak yang akan diperiksa pada lembar observasi yang terdiri dari nama, tempat tanggal lahir, jenis kelamin dan alamat. Peneliti melakukan pemeriksaan oral dengan menggunakan kaca mulut dan juga senter untuk melihat gigi insisivus satu pemanen rahang bawah yang telah erupsi dan mencatatnya dalam lembar observasi. Tahapan munculnya gigi ke dalam rongga mulut dapat diklasifikasikan menjadi empat tahap yaitu $0.00=$ gigi belum terlihat di dalam rongga mulut, $0.25=$ cusp terlihat $0.50=$ setengah mahkota terlihat $1.00=$ erupsi sempurna (8).Peneliti mengambil dokumentasi.

\section{HASIL DAN PEMBAHASAN}

\section{Karakteristik Penelitian di pegunungan}

Penelitian yang dilakukan daerah pegunungan Kecamatan Tulakan sebanyak 117 siswa yang terdiri dari 59 siswa laki-laki dan 58 siswa perempuan. Perolehan data diambil dari SDN Kalikuning 1, SDN Bungur 1, SDN Gasang 1 dan MIN 1 Pacitan, diperoleh data umur untuk daerah pegunungan Kecamatan Tulakan sebanyak 72 siswa berumur 6 tahun dan 45 siswa berumur 7 tahun. Perolehan data diambil dari SDN Kalikuning 1, SDN Bungur 1, SDN Gasang 1 dan MIN 1 Pacitan

Tabel 1 Karakteristik sampel di pegunungan

\begin{tabular}{clc}
\hline \multicolumn{2}{c}{ Variabel Karakteristik } & N \\
\hline Usia & 6 Tahun & 72 \\
& 7 Tahun & 45 \\
\multirow{2}{*}{ Jenis Kelamin } & Laki-laki & 59 \\
& Perempuan & 58 \\
\hline
\end{tabular}

\section{Karakteristik penelitian di pesisir pantai}

Karakteristik daerah pesisir pantai Kecamatan Ngadirojo sebanyak 116 siswa yang terdiri dari 66 siswa laki-laki dan 50 siswa perempuan. Perolehan data diambil dari SDN Sidomulyo 4, SDN Ngadirojo 1, dan SD Islam Nurul Yaqin Pacitan, diperoleh data umur untuk daerah pegunungan Kecamatan Tulakan sebanyak 74 siswa berumur 6 tahun dan 42 siswa berumur 7 tahun. Perolehan data diambil dari SDN Sidomulyo 4, SDN Ngadirojo 1, dan SD Islam Nurul Yaqin Pacitan.

Tabel 2 Karakteristik sampel di pesisir pantai

\begin{tabular}{clc}
\hline \multicolumn{2}{c}{ Variabel Karakteristik } & N \\
\hline Usia & 6 Tahun & 74 \\
& 7 Tahun & 42 \\
\multirow{3}{*}{ Jenis Kelamin } & Laki-laki & 66 \\
& Perempuan & 50 \\
\hline
\end{tabular}


Home page: http://ejurnal.poltekkestasikmalaya.ac.id/index.php/jikg/index

\section{Hasil pengumpulan data}

Tabel 3 Hasil Pengumpulan Data Erupsi Gigi Insisivus Pertama Permanen Rahang Bawah \pm Standar Deviasi Pegunungan Kabupaten Pacitan

\begin{tabular}{llllll}
\hline gigi & \multicolumn{3}{c}{ Erupsi Gigi } & N \\
\cline { 2 - 5 } & $\begin{array}{l}\text { Cusp } \\
\text { belum terlihat }\end{array}$ & cusp terlihat & Setengah mahkota terlihat & Erupsi sempurna & \\
\hline $\mathbf{3 1}$ & $35 \pm$ & $20 \pm$ & $32 \pm 0,498$ & $30 \pm 0,481$ & 117 \\
& 0,501 & 0,479 & $27 \pm 0,504$ & $29 \pm 0,485$ & 117 \\
\hline $\mathbf{4 1}$ & $36 \pm$ & $25 \pm$ & & & \\
& 0,500 & 0,448 & & & \\
\hline
\end{tabular}

Berdasarkan tabel 3 didapatkan hasil pada daerah pegunungan untuk elemen gigi 31

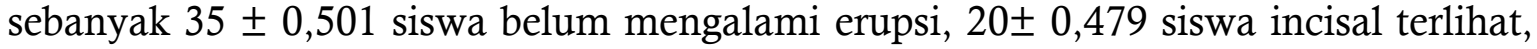
$32 \pm 0,498$ siswa setengah mahkota terlihat dan $30 \pm 0,481$ siswa sudah mengalami erupsi gigi sempurna. Pada gigi 41 sebanyak $36 \pm 0,500$ siswa belum erupsi, $25 \pm$ 0,448 siswa incisal terlihat, $27 \pm 0,504$ siswa setengah mahkota terlihat dan $29 \pm 0,485$ siswa sudah mengalami erupsi sempurna.

Tabel 4 Hasil Pengumpulan Data Erupsi Gigi Insisivus Pertama Permanen Rahang Bawah \pm Standar Deviasi Daerah Pesisir Pantai Kabupaten Pacitan

\begin{tabular}{|c|c|c|c|c|c|c|}
\hline \multirow{2}{*}{$\begin{array}{c}\text { Letak } \\
\text { Geografis }\end{array}$} & \multicolumn{4}{|c|}{ Erupsi gigi 41} & \multirow{2}{*}{$\begin{array}{c}\text { Kolmogoro } \\
\text { v smirnov }\end{array}$} & \multirow[t]{2}{*}{$P$ Value } \\
\hline & $\begin{array}{l}\text { Belum } \\
\text { erupsi }\end{array}$ & $\begin{array}{l}\text { Incisal } \\
\text { terliha } \\
\mathrm{t}\end{array}$ & $\begin{array}{l}\text { Seteng } \\
\text { ah } \\
\text { mahk } \\
\text { ota } \\
\text { terliha } \\
\mathrm{t}\end{array}$ & $\begin{array}{l}\text { Erup } \\
\text { si } \\
\text { semp } \\
\text { urna }\end{array}$ & & \\
\hline Pegunungan & $\begin{array}{l}36 \pm \\
0,500\end{array}$ & $\begin{array}{l}25 \pm \\
0,448\end{array}$ & $\begin{array}{l}27 \pm \\
0,504\end{array}$ & $\begin{array}{l}29 \pm \\
0,485\end{array}$ & 0.000 & 0,003 \\
\hline Pesisir pantai & $\begin{array}{l}28 \pm \\
0,504\end{array}$ & $\begin{array}{l}9 \pm 0,5 \\
07\end{array}$ & $\begin{array}{l}29 \pm \\
0,503\end{array}$ & $\begin{array}{l}50 \pm \\
0,496\end{array}$ & 0.000 & \\
\hline Total & 64 & 34 & 56 & 79 & & \\
\hline
\end{tabular}

Berdasarkan tabel 4 didapatkan hasil pada daerah pesisir pantai untuk elemen gigi 31 sebanyak $28 \pm 0,502$ siswa belum mengalami erupsi, $10 \pm 0,504$ siswa incisal terlihat, $23 \pm 0,498$ siswa setengah mahkota terlihat dan $55 \pm 0,503$ siswa sudah mengalami erupsi gigi sempurna. Pada gigi 41 sebanyak $28 \pm 0,504$ siswa belum erupsi, $9 \pm 0,507$ siswa incisal terlihat, $29 \pm 0,503$ siswa setengah mahkota terlihat dan $50 \pm 0,496$ siswa sudah mengalami erupsi sempurna. 


\section{Hasil Analisis Data}

Tabel 5 Erupsi gigi insisivus pertama permanen rahang bawah kiritstandar deviasi, normalitas data dan uji chi-square

\begin{tabular}{|c|c|c|c|c|c|c|}
\hline \multirow{2}{*}{$\begin{array}{c}\text { Letak } \\
\text { Geografis }\end{array}$} & \multicolumn{4}{|c|}{ Erupsi gigi 31} & \multirow{2}{*}{$\begin{array}{l}\text { Kolmogorov } \\
\text { smirnov }\end{array}$} & \multirow[t]{2}{*}{$P$ Value } \\
\hline & $\begin{array}{l}\text { Belum } \\
\text { erupsi }\end{array}$ & $\begin{array}{l}\text { Incis } \\
\text { al } \\
\text { terlih } \\
\text { at }\end{array}$ & $\begin{array}{l}\text { Seteng } \\
\text { ah } \\
\text { mahko } \\
\text { ta } \\
\text { terlihat }\end{array}$ & $\begin{array}{l}\text { Erup } \\
\text { si } \\
\text { semp } \\
\text { urna }\end{array}$ & & \\
\hline Pegunungan & $\begin{array}{l}35 \pm \\
0,501\end{array}$ & $\begin{array}{l}20 \pm \\
0,479\end{array}$ & $\begin{array}{l}32 \pm 0,4 \\
98\end{array}$ & $\begin{array}{l}30 \pm \\
0,481 \\
\end{array}$ & 0.000 & \\
\hline Pesisir pantai & $\begin{array}{l}28 \pm \\
0,502\end{array}$ & $\begin{array}{l}10 \pm \\
0,504\end{array}$ & $\begin{array}{l}23 \pm 0,4 \\
98\end{array}$ & $\begin{array}{l}55 \pm \\
0,503\end{array}$ & 0.000 & 0,005 \\
\hline Total & 63 & 30 & 55 & 85 & & \\
\hline
\end{tabular}

Berdasarkan tabel 5 didapatkan hasil untuk uji normalitas data gigi 31 daerah pegunungan dan pesisir pantai sebesar 0.000 sehingga sig $\leq 0,05$ yang menunjukkan bahwa data tidak normal. Uji chi-square elemen gigi 31 menunjukkan nilai sig 0,005 sehingga sig $\leq 0,05$. Hal ini berarti bahwa $\mathrm{H} 1$ diterima yaitu terdapat perbedaan erupsi gigi insisivus pertama permanen rahang bawah kiri berdasarkan letak geografis daerah pesisir pantai dan pegunungan Kabupaten Pacitan. Perbedaan yang paling terlihat yaitu pada tingkatan erupsinya, pada daerah pesisir pantai sebanyak 55 sudah mengalami erupsi sempurna sedangkan pada daerah pegunungan hanya sebanyak 30 yang sudah mengalami erupsi sempurna

Tabel 6 Erupsi gigi insisivus pertama permanen rahang bawah kanan \pm standar deviasi, normalitas data dan uji chi-square

\begin{tabular}{|c|c|c|c|c|c|}
\hline \multirow{2}{*}{$\begin{array}{l}\text { Gi } \\
\text { gi }\end{array}$} & \multicolumn{4}{|c|}{ Erupsi Gigi } & \multirow[t]{2}{*}{$\mathbf{N}$} \\
\hline & $\begin{array}{l}\text { Cusp } \\
\text { belum } \\
\text { terlihat }\end{array}$ & $\begin{array}{l}\text { cusp } \\
\text { terlihat }\end{array}$ & $\begin{array}{l}\text { Setengah } \\
\text { mahkota } \\
\text { terlihat }\end{array}$ & $\begin{array}{l}\text { Erupsi } \\
\text { sempur } \\
\text { na }\end{array}$ & \\
\hline 31 & $\begin{array}{l}28 \pm \\
0,502\end{array}$ & $\begin{array}{l}10 \pm \\
0,504\end{array}$ & $23 \pm 0,498$ & $\begin{array}{l}55 \pm 0,5 \\
03\end{array}$ & 116 \\
\hline 41 & $\begin{array}{l}28 \pm \\
0,504\end{array}$ & $\begin{array}{l}9 \pm \\
0,507\end{array}$ & $29 \pm 0,503$ & $\begin{array}{l}50 \pm 0,4 \\
96\end{array}$ & 116 \\
\hline
\end{tabular}

Berdasarkan tabe 16 didapatkan hasil untuk uji normalitas data gigi 41 daerah pegunungan dan pesisir pantai sebesar 0.000 sehingga sig $\leq 0,05$ yang menunjukkan bahwa data tidak normal. Uji chi-square elemen gigi 41 nilai sig 0,003 sehingga sig $\leq$ 0,05 . Hal ini menunjukkan bahwa $\mathrm{H} 1$ diterima yang berarti terdapat perbedaan erupsi gigi insisivus pertama permanen rahang bawah kanan berdasarkan letak geografis daerah pesisir pantai dan pegunungan Kabupaten Pacitan. Perbedaan tersebut dapat dilihat juga berdasarkan tingkatan erupsinya. Pada daerah pesisir pantai sebanyak 50 sudah mengalami erupsi sempurna sedangkan pada daerah pegunungan hanya sebanyak 29 yang sudah mengalami erupsi sempurna.

Kesimpulan yang diperoleh dari dua tabel hasil analisis data diatas dengan menggunakan uji chi-square bahwa $\mathrm{H} 1$ diterima yang berarti terdapat perbedaan erupsi 
gigi insisivus pertama permanen rahang bawah berdasarkan letak geografis pesisir pantai dan pegunungan Kabupaten Pacitan. Perbedaan yang didapatkan yaitu bahwa letak geografis daerah pegunungan mengalami perlambatan erupsi gigi insisivus pertama permanen rahang bawah daripada letak geografis daerah pesisir pantai

\section{PEMBAHASAN}

Berdasarkan hasil analisis data didapatkan perbedaan erupsi gigi insisivus pertama permanen rahang bawah berdasarkan letak geografis daerah pesisir pantai dan pegunungan Kabupaten Pacitan. Perbedaan yang diperoleh yaitu bahwa erupsi gigi insisivus pertama permanen rahang bawah pada letak geografis daerah pegunungan mengalami perlambatan erupsi dibandingkan dengan letak geografis daerah pesisir pantai.

Perbedaan yang didapat ini kemungkinan dipengaruhi oleh letak geografis. Letak geografis mempengaruhi jenis makanan masyarakat pada setiap daerah. Dilihat dari keadaan geografi dan sumber daya perairan, masyarakat di daerah pantai sebagian besar adalah nelayan yang banyak mengkonsumsi makanan sumber protein hewani yang berasal dari laut seperti ikan, sedangkan masyarakat didaerah pegunungan sebagian besar adalah petani sawah atau ladang sehingga lebih banyak mengkonsumsi makanan sumber karbohidrat dan protein nabati. Bahan pangan sumber protein pada daerah pantai dapat terpenuhi setiap hari dengan baik. Hal ini dikarenakan hasil laut yang juga dikonsumsi oleh keluarga sendiri ${ }^{(4)}$.

Hal ini sejalan dengan penelitian yang dilakukan oleh Wahyuningsih, dkk (2014) bahwa perbedaan geografi dan topografi dapat memberikan ciri khusus pada pola pangannya. Dilihat dari keadaan geografi dan sumber daya perairan, masyarakat di daerah pantai sebagian besar adalah nelayan yang banyak mengkonsumsi makanan sumber protein hewani yang berasal dari laut seperti ikan, sedangkan masyarakat didaerah pegunungan sebagian besar adalah petani sawah atau ladang sehingga lebih banyak mengkonsumsi makanan sumber karbohidrat dan protein nabati ${ }^{(9)}$.

Potensi sumber pangan di masyarakat pantai sebagian besar adalah ikan atau sumber protein, mata pencaharian masyarakat pantai adalah nelayan, dan sebagian kecilnya ada yang bertani sawah dan ladang, bertani tambak atau berdagang. Sedangkan potensi sumber pangan di daerah pegunungan adalah beras, singkong dan jagung yang mempunyai sumber karbohidat, mata pencaharian masyarakat pegunungan sebagian besar adalah bertani sawah atau ladang. Dengan demikian kemungkinan masyarakat pantai banyak mengkonsumsi sumber protein dan masyarakat pegunungan banyak mengkonsumsi sumber karbohidrat atau energi ${ }^{(9)}$.

Penelitian yang dilakukan oleh Fitriyanti (2014) juga menunjukkan bahwa sebagian besar subyek di daerah pesisir pola konsumsi ikannya termasuk kedalam kategori sering sekali dengan presentase $42 \%$, sering $24 \%$, kadang $17 \%$, jarang dan jarang sekali $0 \%$. Hal ini disebabkan karena perbedaan frekuensi pola konsumsi makanan di suatu daerah dapat dipengaruhi oleh persediaan bahan pangan, sedangkan tersedianya sumber bahan pangan tergantung dengan faktor-faktor seperti letak geografi, iklim, sumber daya perairan, jenis pekerjaan dan transportasi ${ }^{(10)}$. 
Daerah pesisir rata-rata penduduk bekerja sebagai nelayan sehingga ketersediaan ikan di daerah pesisir dalam jumlah banyak dan ikan yang didapatkan relative segar. Umumnya keluarga nelayan mengkonsumsi ikan yang berasal dari hasil melaut. Sedangkan pada daerah pegunungan pola konsumsi ikan termasuk dalam kategori sering sekali sebanyak $0 \%$, sering $20 \%$, kadang-kadang dengan prosentase $70 \%$, jarang $10 \%$, jarang sekali $0 \%$. Hal ini disebabkan karena masyarakat di daerah pegunungan sebagian besar mempunyai mata pencaharian sebagai petani ${ }^{(10)}$.

Letak geografis daerah pegunungan yang jauh dari pantai mempengaruhi ketersediaan ikan, selain itu karena letak daerah pegunungan yang jauh dari pasar ikan mempengaruhi lamanya waktu transportasi sehingga jumlah ikan yang terdistribusi ke daerah pegunungan sedikit. Terbatasnya jumlah ikan di daerah pegunungan mempengaruhi pola konsumsi masyarakat,akibatnya terdapat perbedaan keadaan rongga mulut pada anak dengan konsumsi ikan dan tidak ${ }^{(10)}$.

Hasil laut yang salah satunya yaitu ikan merupakan sumber protein dan kalsium dengan kualitas tinggi. Ikan laut yang banyak dikonsumsi masyarakat di daerah pesisir, mengandung $18 \%$ protein yang terdiri dari asam amino essensial dan $1-20 \%$ lemak yang mudah dicerna oleh jaringan tubuh ${ }^{(10)}$.

Ikan laut memiliki banyak kandungan fluor. Kandungan gizi yang ada pada ikan laut selain fluor mengandung $18 \%$ protein yang terdiri dari $1-20 \%$ lemak yang mudah dicerna oleh jaringan dan asam amino essensial. Sebagian besar kandungan lemaknya adalah asam lemak tak jenuh yang dibutuhkan untuk pertumbuhan ${ }^{(10)}$.

Kandungan gizi ikan ini sangat bagus untuk tulang dan gigi. Makanan dengan kualitas dan konsentrasi protein dan kalsium yang tinggi mempunyai hubungan linier dengan pertumbuhan dan perkembangan tulang dan gigi. Hal ini disebabkan protein merupakan makanan yang mengandung banyak asam amino sebagai unsur pembangun struktur jaringan tubuh, sedangkan kalsium merupakan mineral penting yang berperan dalam seluruh proses metabolisme tulang dan gigi ${ }^{(5)}$.

Faktor lain yang mempengaruhi erupsi gigi yaitu umur. Berdasarkan data bahwa siswa yang berumur 6 tahun lebih banyak daripada siswa yang berumur 7 tahun baik di daerah pegunungan maupun pesisir pantai. Hal ini sejalan dengan laporan penelitian yang dilakukan oleh Indriyanti, dkk (2006) tentang pola erupsi gigi permanen ditinjau dari usia kronologis pada anak usia 6 sampai 12 tahundi SDN Sirnasari Desa Ciptasari Kecamatan Pamulihan Kabupaten Sumedang bahwa waktu erupsi gigi rahang bawah, gigi insisif pertama erupsi pada umur rata-rata 6,00 tahun ${ }^{(2)}$.

Tetapi berdasarkan penelitian Lantu, dkk (2015) di Manado yang merupakan daerah pesisir pantai. Hasilnya dari 49 responden usia 6-7 tahun didapat $53 \%$ belum mengalami erupsi gigi dan $47 \%$ sudah mengalami erupsi gigi ${ }^{(7)}$.Hal ini menandakan bahwa di daerah pesisir pantai mengalami perlambatan erupsi gigi, tidak sesuai dengan teori yang telah di kemukakan oleh Bozini, dkk (2011).

Penelitian Rahmawati (2014) di Kecamatan Kasihan Bantul, DIY yang merupakan daerah pegunungan sebagian besar penduduk bekerja sebagai petani, dan mengkonsumsi sumber makanan protein nabati. Hasilnya di dapatkan 30 siswa usia 67 tahun status gizi baik, yang sudah erupsi 28 (80\%) dan yang belum erupsi $2(20 \%)$. 
Tahapan erupsi gigi yang sudah erupsi sempurna $75 \%$, erupsi sebagian $21,7 \%$ dan belum erupsi $3,3 \%$. Hal ini menandakan terjadinya percepatan erupsi pada daerah pegunungan ${ }^{(6)}$.

Hasil yang berbanding terbalik ini disebabkan oleh beberapa hal. Berdasarkan penelitian yang dilakukan oleh Hamidah, dkk (2016) bahwa bahan makanan sumber protein yang dikonsumsi keluarga di wilayah dataran tinggi lebih beragam dibandingkan dengan daerah dataran rendah dan dearah pantai. Walaupun tinggal di daerah dataran tinggi, tetapi masyarakat ternyata juga mengkonsumsi bahan makanan sumber protein dari hasil laut seperti udang, kerang, cumi-cumi dan ikan asin, serta ikan tawar, selain mengkonsumsi tahu tempe dan hasil ternak kecil seperti ayam serta telur ayam ${ }^{(11)}$.

Hal ini bisa disebabkan oleh pembangunan infrastruktur di wilayah tersebut yang baik sehingga memudahkan keluarga memperoleh berbagai jenis bahan makanan yang dibutuhkan. Ketersediaan sarana transportasi yang baik ketersediaan bahan-bahan makanan laut cukup tinggi di wilayah tersebut, baik melalui pedagang keliling, warung, atau pasar ${ }^{(11)}$.

Hasil penelitian ini juga sejalan dengan penelitian yang dilakukan oleh Pangerapan, dkk (2018) di Dusun Rarumis Desa Karor Kecamatan Lembean Timur yang menyatakan bahwa walaupun masyarakat tinggal di pesisir pantai, tetapi pekerjaan mereka sebagian besar adalah bertani, dan ada juga sebagai buruh tani, nelayan hanya pekerjaan sampingan. Dilihat dari pandangan tersebut masyarakat yang berada di pesisir pantai pendapatan tidak menetap sehingga mempengaruhi konsumsi. Aktivitas ekonomi penduduk di dominasi dengan sektor pertanian dan perkebunan, sebagian besar lahan yang ada digunakan oleh petani untuk melakukan kegiatan usaha tani seperti menanam rica, jagung, kelapa dan cengkih, kacang tanah, pisang yang dijadikan sebagai sumber pendapatan oleh masyarakat pesisir pantai ${ }^{(12)}$.

Perbedaan hasil erupsi gigi ini juga dipengaruhi oleh status gizi. Anak-anak dengan status gizi baik mencerminkan terpenuhinya asupan gizi yang seimbang sehingga memiliki kesehatan umum yang baik, karena terpenuhinya zat-zat gizi penting seperti karbohidrat, protein, kalsium, mineral dan vitamin. Pada masa pra-erupsi gigi, zat-zat gizi seperti protein, kalsium, vitamin dan mineral memiliki peran yang penting dalam pembentukan struktur gigi ${ }^{(13)}$.

Faktor sosial ekonomi juga menjadi salah satu faktor yang mempengaruhi erupsi gigi. Tingkat sosial ekonomi keluarga merupakan salah satu faktor yang menentukan makanan yang tersedia dalam keluarga Ketersediaan bahan pangan sumber protein pada daerah pegunungan yang mempunyai jumlah jauh lebih sedikit dibandingkan dengan daerah pantai dan harganya yang tidak murah mempengaruhi pola konsumsi ikan. Harga ikan yang mahal menjadi salah satu penyebab kurangnya masyarakat daerah pegunungan untuk rutin mengkonsumsi ikan ${ }^{(14)}$. Berdasarkan pemaparan tersebut dapat ditarik kesimpulan bahwa faktor sosial ekonomi menjadi salah satu faktor yang menyebabkan terjadinya perlambatan erupsi gigi pada daerah pegunungan.

Sejalan dengan penelitian yang dilakukan Almonaitiene, dkk (2010) bahwa anak yang memiliki latar belakang sosio ekonomi lebih tinggi mendapatkan pelayanan kesehatan 
dan nutrisi yang lebih baik sehingga mempengaruhi perkembangan gigi yang terjadi lebih awal ${ }^{(1)}$.

Jenis kelamin merupakan salah satu faktor lain yang mempengaruhi erupsi gigi. Hasil penelitian yang dilakukan oleh Marjianto, dkk (2019) tentang erupsi gigi permanen berdasarkan usia kronologis dan jenis kelamin pada anak usia 6-12 tahun di Madura menujukkan bahwa gigi tetap pada jenis kelamin perempuan secara kronologis pada usia 6-12 tahun erupsi lebih awal daripada anak dengan jenis kelamin laki-laki. Erupsi paling awal terjadi pada gigi kaninus mandibula permanen anak perempuan ${ }^{(15)}$.

Berdasarkan pemaparan diatas penulis dapat menarik kesimpulan bahwa terjadinya perbedaan erupsi gigi di daerah pesisir pantai dan pegunungan tidak hanya dipengaruhi oleh faktor geografis. Faktor geografis hanya menjadi satu dari sekian banyak faktor yang mempengaruhi erupsi gigi. Banyak faktor lain yang mempengaruhi seperti status gizi, umur, jenis kelamin, sosial ekonomi, genetik, ras dan lainnya.

\section{KESIMPULAN}

Berdasarkan penelitian hasil analisis data didapatkan kesimpulan bahwa terdapat perbedaan waktu erupsi gigi insisivus pertama permanen rahang bawah berdasarkan letak geografis pesisir pantai dan pegunungan Kabupaten Pacitan. Perbedaan yang diperoleh yaitu bahwa erupsi gigi insisivus pertama permanen rahang bawah pada letak geografis daerah pegunungan mengalami perlambatan erupsi dibandingkan dengan letak geografis daerah pesisir pantai.Disarankan untuk dapat digunakan sebagai acuan untuk dapat dikembangkan pada penelitian selanjutnya dengan menambahkan variabel lain yang diteliti yaitu dengan menambahkan variabel umur, status gizi, jenis kelamin dan sosial ekonomi.

\section{DAFTAR PUSTAKA}

1. Almonaitiene R., Balciuniene I.,Tutkuviene J. 2010. Factors influencing permanent teeth eruption. Part one--general factors. Stomatologija / issued by public institution 'Odontologijos studija' ... [et al.]. 12(3):67-72. DOI: https://sbdmj.1smuni.lt/103/103-01.pdf

2. Indriyanti R., Pertiwi A., Sasmita I. 2006. Pola erupsi gigi permanen ditinjau dari usia kronologis pada anak usia 6 sampai 12 tahun di kabupaten sumedang. Pola Erupsi Gigi Permanen Ditinjau Dari Usia Kronologis Pada Anak Usia 6 Sampai 12 Tahun Di Kabupaten Sumedang. 138: 1-25. DOI: http://pustaka.unpad.ac.id/wpcontent/uploads/2009/05/pola erupsi gigi permanen.pdf

3. Dispendukcapil. 2017. Profil Kependudukan Kabupaten Pacitan. Pacitan: Dinas Kependudukan dan Pencatatan Sipil. Hal: 35-40

4. Auliya C., Oktia Woro., Irwan B. 2014.Profil Status Gizi Balita Ditinjau dari Topografi Wilayah Tempat Tinggal (Studi Wilayah Pantai dan Wilayah Punggung Bukit Kabupaten Jepara). Unnes Journal of Public Health. 3(1): 1-10. DOI:https://doi.org/10.15294/ujph.v4i2.5739.

5. Bozzini C. E., dkk. 2011. Bone mineral density and bone strength from the mandible of chronically protein restricted rats. Acta odontológica latinoamericana: AOL. 24(3): 223-228.DOI:22550813 
6. Rahmawati A D., Retriasih H., Medawati A. 2014. Hubungan antara Status Gizi dengan Status Erupsi Gigi Insisivus Sentralis Permanen Mandibula. Idj. 3(1): 1621.DOI: https://doi.org/10.18196/idj.v3i1.1724.

7. Lantu V. A. R., Kawengian S. E. S., Wowor V. N. S. 2015. Hubungan Status Gizi Dengan Erupsi Gigi Permanen Siswa Sd Negeri 70 Manado. e-GIGI. 3(1):189-196. DOI: https://doi.org/10.35790/eg.3.1.2015.6849.

8. Kutesa A., dkk. 2013. Weight, height and eruption times of permanent teeth of children aged 4-15 years in Kampala, Uganda. BMC Oral Health. BMC Oral Health. 13(1):1. DOI: 10.4236/ojst.2011.11002.

9. Wahyuningsih S., Hardjono S., Suparwitri S. 2014. Perawatan Maloklusi Angle Klas I dengan Gigi Depan Crowding Berat dan Cross Bite Menggunakan Teknik Begg pada Pasien dengan Kebersihan Mulut Buruk. Majalah Kedokteran Gigi Indonesia. 21(2): 204-211. DOI: https://doi.org/10.22146/majkedgiind.8758

10. Fitriyanti A., Susilowati A., N.A. Darjono. 2014. Perbedaan Pola Konsumsi Ikan Dan Status Kesehatan Gigi Dan Mulut Pada Anak Usia Sekolah Dasar (7-12 Th) Di Daerah Pesisir Dan Non Pesisir Kabupaten Jepara Tahun 2012.ODONTO: Dental Journal. 1(1): 6-10. DOI: http://dx.doi.org/10.30659/odj.1.1.6-10.

11. Hamida S., Sartono A., Kusuma H. S.2017. Perbedaan pola konsumsi bahan makanan sumber protein keluarga di daerah pantai, dataran rendah dan dataran tinggi. Jurnal Gizi. 6(1): 21-28. DOI: https://doi.org/10.26714/jg.6.1.2017.\%25p.

12. Pangerapan M., Laoh., Tangkere E. 2019. Analisis Pendapatan Dan Konsumsi Masyarakat Pesisir Pantai (Studi Kasus: Di Dusun Rarumis Desa Karor Kecamatan Lembean Timur) Mianty. Journal of Chemical Information and Modeling. 53(9): 1689-1699. DOI: http://dx.doi.org/10.35791/agrsosek.14.1.2018.18960.

13. Istiany, A. 2013. Gizi Terapan. Bandung: PT. Remaja Rosdakarya. Hal: 37-40

14. Supariasa N, Bakri B, Fajar I. 2014. Penilaian status gizi. Jakarta: Buku Kedokteran ECG. Hal: 103-107

15. Marjianto A., Sylvia Mieke., Wahluyo Soegeng. 2019.Permanent tooth eruption based on chronological age and gender in 6-12-year old children on Madura. Dental Journal. 52(2): 100-104. http://dx.doi.org/10.20473/j.djmkg.v52.i2.p100-104 